\title{
The adequacy of IFRS 15 for revenue recognition in the construction industry
}

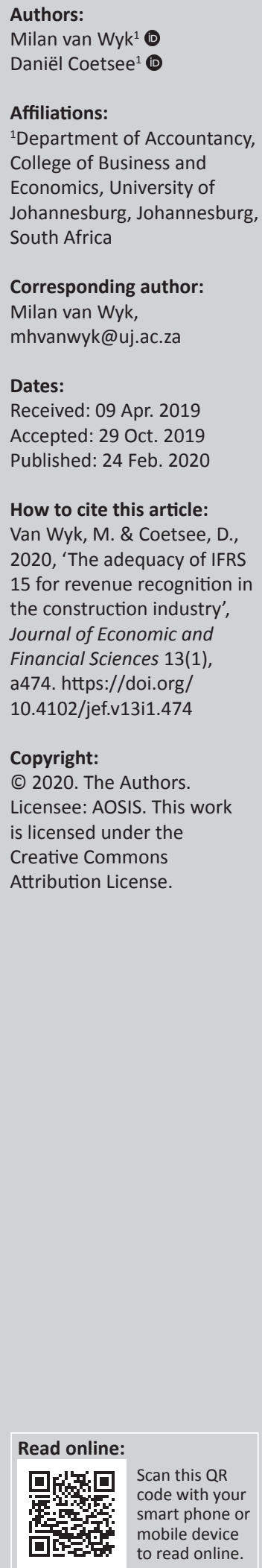

Orientation: The International Financial Reporting Standard 15 (IRFS 15) Revenue from Contract with Customers replaced, amongst others, the industry-specific financial reporting standard (i.e. International Accounting Standard 11 [IAS 11] Construction Contracts), becoming effective on or after 01 January 2018. Construction is regarded as a complex industry with regular changes in contract scope and pricing.

Research purpose: The objective of this article was to evaluate the adequacy of the guidance of the IFRS 15 to deal with the complexities of the construction industry in order to recognise revenue derived from construction contracts. In evaluating the application of the principles of the IFRS 15 to construction contracts, a structured approach was followed based on the fivestep approach followed in the IFRS 15.

Motivation for the study: The lack of industry-specific guidance for construction revenue, together with the complexities of the construction industry, makes the application of the IFRS 15 challenging for construction entities.

Research approach/design and method: The revenue recognition principles developed in the IFRS 15 were assessed through doctrinal research, a research method focusing on the core doctrines developed in practice. Reform-oriented doctrinal research was used to assess the doctrines developed in the IFRS 15 by applying authoritative interpretation.

Main findings: This article found that the IFRS 15 provides an appropriate framework for the revenue recognition of construction contracts. However, the application of the guidance is based on the correct interpretation of the rights and obligations in construction contracts, which could create uncertainties in practice. Significant areas of estimation uncertainty and judgements should be disclosed.

Practical/managerial implications: The implications of the IFRS 15 are that construction entities need to understand the rights and obligations in contracts and how these affect the revenue recognition of construction contracts.

Contribution/value-add: This article provided insights into the application of the IFRS 15 to construction contracts.

Keywords: construction contracts; financial reporting; over time; performance obligations; point in time; revenue recognition; transaction price.

\section{Background and research problem}

Revenue is regarded as one of the most significant measures of financial performance (Wagenhofer 2014). Dobler (2008) considers revenue to be a crucial number in financial reporting, which could be used for accounting manipulation. To improve revenue recognition, the International Accounting Standards Board (IASB) issued a comprehensive standard, the International Financial Reporting Standard 15 (IFRS 15) Revenue from Contracts with Customers in May 2014. The IFRS 15 supersedes, amongst others, International Accounting Standard 11 (IAS 11) Construction Contracts for all financial year-ends starting from 01 January 2018.

PricewaterhouseCoopers (PwC) South Africa (2013) indicates that numerous aspects of the construction industry are considered to be complex because of the size and length of the projects and the dynamic nature of such projects. Mulder (2013) and Ivory (2005) also make reference to the complex relationships in construction contracts and the ever-changing environment with tight budgets and deadlines because of high competition. According to Van der Puil and 
Van Weele (2013), international construction contracts are even more complex as such entities operate in different cultural environments when delivering multimillion or even multibillion projects.

KPMG (2014) refers to the replacement of the IAS 11 - which provided specific guidance on construction contract accounting - as losing the contract accounting 'rule book' for entities in the construction industry. Therefore, the lack of specific guidance for construction revenue, together with the complexities of the construction industry, might make the application of the IFRS 15 challenging for construction entities. Considering the complexities of the construction industry, and specifically the long-term construction contracts, the question arises whether the all-inclusive requirements of the IFRS 15 will in fact give appropriate guidance for the recognition of revenue from construction contracts.

\section{Research objective, process and scope}

The objective of this article was to evaluate the adequacy of the guidance of the IFRS 15 in dealing with the complexities of the construction industry in order to recognise revenue derived from construction contracts. In evaluating the application of the principles of the IFRS 15 to construction contracts, a structured approach was followed based on the core principle in the IFRS 15, namely, that revenue is recognised as the amount of consideration an entity is expected to be entitled to in transferring the goods or services to a customer. The structured approach is based on evaluating the five-step recognition process of the IFRS 15 (see Figure 1).

The five-step process is assessed independently in this the article. The objective of the research is achieved in an integrated approach under each step of:

- analysing the old revenue recognition requirements for construction contracts under the IAS 11

- analysing the new revenue recognition requirements for construction contracts under the IFRS 15

- critically assessing whether the IFRS 15 requirements provide appropriate guidance for application to construction contracts.

This article is limited to the treatment of revenue in construction contracts and therefore the treatment of contract

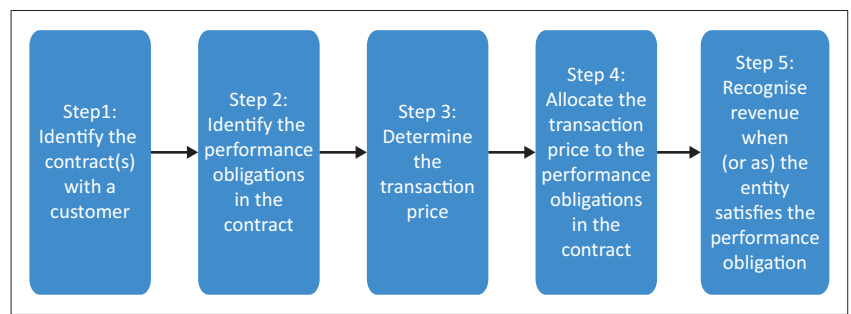

Source: International Accounting Standards Board (IASB), 2014a, 'IFRS 15 revenue from contracts with customers', in IASB (ed.), International Financial Reporting Standards: A guide through IFRS official pronouncements, issued at 01 July 2014 with extensive cross-references and other annotations, Part A1, The IFRS Foundation, London

FIGURE 1: The five steps of the core principle of revenue recognition in International Financial Reporting Standard 15. cost in terms of the IFRS 15 is excluded. Presentation and disclosure issues are also excluded.

\section{Research methodology}

Doctrinal research is used to assess the revenue recognition principles contained in the IFRS 15. Doctrinal research focuses on the rules and principles that govern a specific discipline (in this case, accounting). Hutchinson and Duncan (2012:84) describe doctrines as a 'synthesis of various rules, principles, norms, interpretive guidelines and values'. They explain that doctrinal research is a research method at the core of practice, which in this case is the IFRS 15, as developed by the IASB. Doctrinal research is normally applied within the legal discipline. However, because accounting 'rules' also develop principles which are enforced by law within certain jurisdictions such as South Africa, doctrinal research can also be used within the accounting discipline.

As Gaffikin (2006) notes, professional bodies and independent organisations attempted to create a theoretical basis for accounting practices founded on generally accepted accounting principles. However, as the principles of the standards were not tested as theory through a scientific process (Inanga \& Schneider 2005), they cannot be regarded as theory for traditional research purposes. A traditional research method would therefore not always be appropriate.

Chynoweth (2008) makes reference to doctrinal research as part of the humanities tradition. His view of doctrinal research is that the rules and principles of the discipline are created through human intervention, which forms part of a social research framework. Doctrinal research is carried out within an interpretive and critical framework, depending on the type of research. Chynoweth (2008) also believes that doctrinal research has normative characteristics as it is prescriptive through analysis of doctrines in concluding what it 'ought to be'.

Hutchinson and Duncan (2012:101) refer to a method of doctrinal research known as 'reform-oriented research' whereby the adequacy of the underlying rules and principles is assessed. The evaluation of the existing rules and principles is done through a two-part process (Hutchinson \& Duncan 2012). Firstly, the sources of 'law' are located (in this case, the IFRS 15 and the IAS 11). Subsequently, the principles are interpreted and analysed into a specific context, namely, construction contracts in this article.

Van Hoecke (2011) describes doctrinal research as a hermeneutical approach whereby doctrines in a discipline are assessed through authoritative interpretation. Hermeneutics interprets text to identify meaning in the text (Boland 1989; Gaffikin 2008; Prasad 2002). Van der Spuy (2015:812) defines qualitative doctrinal research approach as ' $[a]$ purely theoretical and documentary analysis which is augmented and complemented with application of discussion and logical argumentation'. 
Authoritative interpretation of both the old guidance in the IAS 11 and the new guidance in the IFRS 15 is supported by other practical and academic literature to assess the adequacy of the new revenue recognition doctrines. Through authoritative interpretation of the above documents based on the five-step approach of the IFRS 15, this article uses logical argumentation to assess whether adequate revenue recognition guidance is provided in each step of the revenue recognition process. The article is therefore limited to the interpretation of the authors based on the supported documentation.

\section{Identification of contracts with the customer Introduction}

In the IFRS 15 (IASB 2014a), the underlying contract establishes the enforceable rights and obligations that form the basis of revenue recognition. The IASB previously identified in the IAS 11 what a construction contract was by providing a specific definition (IASB 2013a):

A contract specifically negotiated for the construction of an asset or combination of assets that are closely interrelated or interdependent in terms of their design, technology and function or their ultimate purpose of use. (para. 3)

Although this definition outlined the scope of a construction contract, it did not provide any guidance as to the requirements to establish enforceable rights and obligations in a contract. Previously, the construction industry considered the construction contract as a fact of law.

\section{Assessing the validity of a contract and combination of contracts}

In the IFRS 15, a valid contract is a new prerequisite for revenue recognition. The IASB (2014a:para. 9) includes new criteria to identify a valid contract for revenue recognition purposes in order to establish its 'enforceability'. This improves upon the indirect guidance contained in the IAS 11 (IASB 2014b) through a more detailed definition of a construction contract. All the five criteria listed below need to be met in order for a valid contract to exist:

- The parties must have approved the contract and must be committed to perform their respective obligations.

- The entity must be able to identify the rights and obligations regarding the goods or services to be transferred.

- The entity must be able to identify the payment terms of the goods or services to be transferred.

- The contract has commercial substance, meaning goods or services of economic value are transferred.

- It must be probable that the entity will collect the consideration to which it will be entitled.

The first four criteria enable an entity to identify the enforceable rights and obligations in a contract. As confirmed by Randolph and Ellis Jr. (2007), the identification of the rights and obligations could be straightforward for the construction industry if the rights and obligations are clarified in the contract. In addition, Ndlovu (2017) pointed out that there are different forms of contracts in South Africa that would assist in providing standardised and more simplified contracts to clarify the rights and obligations.

With respect to the last criterion, the IASB (2014b) considers the assessment of a customer's credit risk as an important factor in determining whether a contract is valid for revenue recognition purposes in terms of the IFRS 15. This is because the validity of a contract is questioned when the entity does not expect the consideration to be received. Construction entities perform significant construction work that is exposed to significant credit risk on the contract price, which could result in a recognition dilemma in practice. However, if a construction entity has proper credit control procedures in place to ensure that the consideration in construction contracts is expected to be received, the last criterion should be met.

The validation criteria ensure that only enforceable contracts are considered for revenue recognition purposes. The IFRS 15 creates an appropriate framework to assess the rights and obligations in a contract, thus forming the basis for the application of steps $2-5$. The application of these validation criteria should also result in construction entities improving the stipulations of contracts and credit control over time.

\section{Accounting to combine contracts}

The IAS 11 (IASB 2013a:para. 9) provides guidance on combinations of contracts when a number of contracts are entered into with one or more customers. These contracts are treated as a single contract when all three of the following criteria are met:

- The contracts need to be negotiated as a single package.

- The contracts need to be inter-related and, in substance, regarded as a single contract with a single profit margin.

- The contracts need to occur simultaneously or continuously.

As noted by Ernst \& Young (2015a), the IFRS 15 simplifies the combination of contracts by requiring only one or more requirements to be met instead of all the requirements, as per the IAS 11. The first requirement of the IFRS 15 is closely linked to the IAS 11 requirement of negotiating the contracts as a package with a single commercial objective. The second requirement of the IFRS 15 suggests that the consideration paid to one contract should be dependent on the performance of another contract, therefore making it inter-related. The third requirement refers to the promised goods and services in the contracts being so inter-related that they would be regarded as a single performance obligation.

In agreement with PwC (2014), the change in combination criteria should not result in significant changes in practice because the changed criteria still assist in the application of the principle that contracts are collectively considered to be 
one integrated contract with a combined objective because of high inter-relation with each other.

\section{Accounting for contract modifications}

Van der Puil and Van Weele (2013) make reference to the fact that construction entities do not operate in an 'ideal world' and therefore variations are a 'fact of life'. Randolph and Ellis Jr. (2007) mention the two main forms of change orders, namely, written change orders and oral change orders.

According to the IASB in the IFRS 15 (2014a:para. 18), a contract modification exists when there is a change in the scope or price (or both) of a contract, which is approved by the parties. In essence, a modification creates new enforceable rights and obligations in a contract or changes the existing ones. PwC (2014) argues that the previous practice of the IAS 11 to account for contract modifications will not change. However, it is important to distinguish between contract modifications and variable consideration, as this would lead to different treatments in terms of the IFRS 15. The IASB deals with this issue in the IFRS 15 (2014a:para. 19) by stating that if the scope of work has been approved but the price still needs to be determined, the price should be estimated using the guidance of variable consideration. Therefore, a modification exits when the parties agree to change the scope of the work and the price of the contract. In contrast, uncertainties regarding the price in a contract are treated as a variable consideration under Step 3 (refer to the section 'Determining the transaction price').

The IAS 11 did not specifically distinguish between contract modifications and variable consideration. It discussed variations in contract work under guidance on contract revenue and how it affected the revenue to be recognised in the contract (IASB 2013a:para. 13). In the IAS 11, changes to the contract revenue were only applied when it was probable that it would be approved and that the amount could be measured reliably. However, PwC (2014) and the IASB (2014b) note that the IAS 11 failed to provide enough guidance on when or how to account for variation orders, which complicated the accounting application for variation orders under the IAS 11. But, the IFRS 15 provides improved guidance in this regard.

The IASB's (2014b:para. BC76) rationale for including a specific framework on modifications was to ensure that there was consistency with the core objective of 'faithfully depicting the entity's rights and obligations in the modified contract'. Three different treatments for contact modifications are identified in the IFRS 15 (IASB 2014a).

Firstly, the modification is regarded as a separate contact when the modified goods and services are distinct from the goods and services transferred before the modification and the consideration relating to the modification reflects the stand-alone selling price. Prospectively, the old and new contracts are regarded as separate contracts for which revenue is recognised separately.
Secondly, when the products or services delivered to date are completely transferred on the date of modification, the original contract is considered to be cancelled and replaced by a new contract regarding the goods or services still to be transferred in the future at a new price, even if this price does not reflect the stand-alone selling price. Then changes to the old contract are applied prospectively as part of the deemed new contract.

Thirdly, when the delivery of the goods and services is not completed on the date of modification, the revenue in the contract is adjusted retrospectively on a cumulative catch-up basis, where the whole contract position is adjusted to take into account the modification.

In construction, it is likely that the most commonly used method would be the cumulative catch-up method because of the high level of inter-relation between the different goods and services in contracts, which would be regarded as a single performance obligation under Step 2 (refer to the section 'Identifying the performance obligations in the contract'). Ernst \& Young (2015a) shares a similar view that the cumulative catch-up method will be the most commonly used method because of the inter-relation between goods and services in the contract.

The IFRS 15 fulfils its objective of providing a framework for contract modifications by clarifying what a modification represents and identifying the three alternatives under which contract modifications could be treated as a separate contract, a new deemed contract or an existing uncompleted contract for which revenue is adjusted on a cumulative catch-up basis. In agreement with the views of PwC (2014) and Moore Stephens (2018), significant judgements would still be required to assess whether changes in the rights and obligations in a contract are to be considered as a modification or changes in variable considerations.

\section{Identifying the performance obligations in the contract}

Once the validity of the contract is satisfied, it is imperative to assess the contract, at inception, for promises that give rise to separate 'performance obligations' from the perspective of the construction entity. The IASB (2014b) is in agreement that identified promised goods and services in the contract trigger the identification of performance obligations for revenue recognition purposes. The promises in the contract can either be explicitly stated or can be derived from customary business practices as long as the promises are considered to be enforceable (IASB 2014a).

The IFRS 15 (IASB 2014a:para. 22) requires an entity to identify, at contract inception, a performance obligation from each promise to transfer goods and services to the customer that is regarded to be distinct. A series of distinct goods and services that are substantially the same and have the same pattern of transfer to the customer could also be regarded as a combined performance obligation. However, in the author's 
view, a series of distinct goods and services would normally not exist in construction contracts because of the integrated nature of the promised goods and services.

The term 'distinct' is defined in the Oxford Dictionary as an item that is 'recognisably dissimilar', 'different in nature' and 'distinguishable' (Oxford University Press 2016). Ernst \& Young (2015b:1954) refers a 'two-step process' to determine whether a good or service is distinct. Firstly, a 'benefit assessment' must be made, followed by a 'separately identifiable' assessment. The IASB (2014a:para. 28) identifies the two separate assessments as follows: (1) a customer should be able to benefit from the good or service either on its own or together with other readily available resources (assessment done at the level of the promised good or service) and (2) the good or service needs to be separately identifiable from other promises in the contract, within the context of the contract.

The 'benefit assessment' is made on the goods or services' own characteristics, without considering contract limitations. The goods or services should have benefits for the customer in order for them to be transferred to a customer to make them 'capable of being distinct'. The benefit could be obtained by the customer through the transferred asset alone, or in conjunction with other readily available assets of the customer.

The 'separately identifiable' assessment is considered difficult to apply and lead to the Transition Resource Group (TRG) issuing the clarifications to the IFRS 15 for additional guidance on 'separately identifiable', 'combined output' and 'inter-related' factors in the assessment (IASB 2015). The IASB (2016) therefore clarified the factors to be considered in order to determine when goods and services would not be regarded as being separately identifiable within the context of a contract. It is important to note that the factors should not be seen as separate requirements, but as guidance to reduce judgement to determine when goods and services are distinct. The factors to be considered include, but are not limited to:

- goods or services used as inputs to deliver a combined output or outputs

- one or more goods or services significantly modifying other goods and services in the contract

- goods or services that are highly interdependent or interrelated.

According to Morris (2014), a construction contractor's performance obligation to carry out the works under the contract would typically be treated as a single performance obligation in its entirety. The reason is that in construction contracts, the nature of the promised goods and services would normally be inter-related or interdependent and therefore would not meet the requirements of distinct goods and services. Similarly, the definition of a construction contract in the IAS 11 also indicated that construction contracts were 'closely interrelated or interdependent in terms of their design, technology and function' (IASB 2013b:para. 3). Construction contracts therefore usually have a macro-promise in the contract; this is the construction of a specified asset from which only the customer can benefit once it is completed. The result is that revenue in most construction contracts would be treated on a contract level and not separately in different performance obligations (PwC 2014).

The goods and services in construction contracts are used as inputs to produce a final combined output in the form of a constructed asset. The combined output could include the input of different promises of goods or services in a contract, such as design, planning services, engineering services, construction materials and construction services. As these inputs are inter-related, they are normally not regarded as separate performance obligations.

The guidance in the IFRS 15 is adequate to identify different performance obligations in contracts by providing factors that would make promises not separately identifiable in the contract. Construction entities cannot, however, assume that they will always provide one combined contractual output. The assessment of 'distinct' goods and services is a matter of judgement and construction entities need to carefully assess their contracts in order to understand how many performance obligations exist in a contract. In pursuit of improved articulation of whether goods and services are distinct, the IASB could consider improved, industry-related illustrative examples as guidance. Examples could be included to illustrate when promises in a construction contract would or would not be regarded as one combined output.

\section{Determining the transaction price Introduction}

The transaction price is usually stipulated in the contract, but can also be implied as part of the customary business practices of the entity. The transaction price, even if variable, is determined in order to appropriately measure revenue for contracts when or as each performance obligation is satisfied.

The method of determining the transaction price is different in the IFRS 15 compared to the IAS 11. The IFRS 15 (IASB 2014a:para. 47) applies the principle of predicting, at contract inception, the consideration that is expected to be received by the entity in exchange for goods or services. The IAS 11 (IASB 2013b:para. 11), on the other hand, only referred to the components that were included in contract revenue. The IAS 11 components consisted of the agreed price per the contract as well as any variations including changes to contract work or claims or incentives. This is a common but very complex aspect of construction contracts. The IFRS 15 has a strong link with the enforceability of consideration receivable in the contract, which is by implication included in the agreed price in the IAS 11 as it is a part of the amount agreed by the parties in the contract.

\section{Variable consideration}

Variables and uncertainties are synonymous with the construction industry, which is considered to be complex because of the multifaceted customer and subcontractor 
relationships (Mulder 2013). The IASB (2014b:para. BC189) provides structured and detailed guidelines in the IFRS 15 to determine and estimate the variable consideration. Firstly, the variable consideration present in the contract must be identified. Secondly, different estimation methods must be considered. As part of the estimation, consideration needs to be given to any estimates that may be constrained, resulting in variable consideration not being included in the transaction price. Lastly, guidance is provided on how to account for any subsequent changes in estimates.

\section{Identifying variable consideration}

The IFRS 15 (IASB 2014a:para. 52) stipulates that the variable consideration should normally be explicitly stated in the contract. It may also be derived from a 'valid expectation' from normal business practices and 'other facts and circumstances' that might indicate that the entity could provide the customer with a price concession or other price changes (normally referred to as unpriced change orders in the construction industry). This may be the case where a construction entity enters into a contract with a new customer and decides to grant a lower price (price concession) in order to improve customer relationships for possible further contracts. Therefore, it is important to consider all facts and circumstances in the context of the contract to identify possible variable consideration, keeping in mind that it should still be enforceable.

\section{Estimation methods of variable consideration}

Determining variable consideration is based on the principle that any uncertainty regarding the occurrence or the amount of consideration would lead to the consideration being estimated. Ernst \& Young (2015a) states that entities must estimate the variable consideration to which they expect to be entitled at contract inception. This is different from the IAS 11 (2013a), where variables were recognised only when the contract or claim, as part of the contract, had reached an 'advanced stage' and the amount of the variable could be measured reliably at that stage. This could lead to certain variable considerations being recognised significantly earlier in the contract process than under the IAS 11, such as incentive payments (PwC 2014).

The IASB (2014a:para. 53) suggests that there are two methods by which variable consideration can be measured to predict the consideration expected to be entitled to, namely, the 'expected value' and the 'most likely amount'. The expected value is a combination of different probabilities, whereas the most likely amount identifies one outcome that is most likely. In the construction industry, the 'most likely amount' method should normally be applied to incentive payments for performance and achievement of milestones during a contract where the outcome would be either achieving the milestone or not.

\section{Constraining estimates of variable consideration}

The constraint of variable consideration deals with significant uncertainty in estimating the total consideration. According to the IFRS 15 (IASB 2014a:para. 56), variable consideration can only be recognised when it is 'highly probable' that the cumulative revenue recognised relating to the variable consideration will not be reversed. The constraint is considered as a higher threshold in recognising variables such as incentive payments and claims as per the IAS 11, which could result in later recognition of such portions of the variable consideration (PwC 2014), even though the estimation is done at contract inception. The IAS 11 (2013a) followed a more generic approach in considering the probability of the outcome and assessing whether the variable amounts were reliably measured. In the IFRS 15, if material uncertainty exists, variable consideration should not be recognised until that uncertainty is resolved.

However, the term 'highly probable' is not well defined in the IFRS 15 and could lead to uncertainty and confusion in practice, even though the IASB (2014a) provided factors that could increase the likelihood and magnitude of revenue reversal. A possible better way of applying the principle would be to consider whether there is any material uncertainty regarding the recognition and measurement of the variable consideration by applying the constraining factors.

The factors include, amongst others, consideration that is influenced by factors that are outside the control of the entity, limited experience in estimating the variable consideration and having a wide range of amounts and price concessions in determining the consideration. The constraining factors are helpful in applying the constraint guidance but are considered subjective and could result in the need for disclosure of significant judgements and sources of estimation uncertainty, in accordance with the IAS 1, Presentation of Financial Statements (IASB 2014c). KPMG (2014) is also of the opinion that these constraining factors would be a critical judgement and that an entity's past experience could be used to resolve the application of the constraint.

\section{Subsequent changes in variable consideration}

The IFRS 15 (IASB 2014a:para. 59) suggests that an entity needs to reassess the variable consideration and the effect of the constraint at the end of each reporting period in order to predict the future consideration that the entity would be entitled to and to provide information that is relevant to users. These changes in estimates need to be allocated to the relevant performance obligations, which, in the case of the construction industry, would normally be the construction contract as a whole.

\section{Conclusion on variable consideration}

Variable consideration is only included in the transaction price when uncertainties surrounding the constraining estimates are resolved. Baloi and Price (2003) suggest that in construction, experience of the assumptions used and human judgement play a significant role in the uncertainties and, specifically, in construction risk management.

The systematic guidance in the IFRS 15 provides a better framework to deal with uncertainties in determining the 
amount of consideration in a contract. However, the application of the constraint for the recognition of variable consideration is problematic and could result in uncertainty in practice. Judgements in determining the amount of variable consideration could trigger crucial disclosures in the notes to the financial statements as well as in key accounting policies of the construction entity. This would ensure that users of financial statements could understand the judgements made in recognising the revenue and, more specifically, relating to variable consideration to predict future revenue.

\section{Significant financing component}

The IFRS 15 clarifies how and when a significant financing component should be identified. Such guidance was not included in the IAS 11. Significant financing components in a contract should be recognised separately. As a practical expedient, a financing component does not need to be identified for short-term contracts lasting a year or less. In order to improve guidance on identifying significant financing components, the IASB (2014a) added circumstances when a significant financing component does not exist, making the guidance easier for construction entities to apply. One such circumstance is when payments are made to protect the construction company from the risk of non-fulfilment of the payment obligations of the customer. Significant upfront deposits in construction contracts therefore do not necessarily result in the identification of a financing component.

\section{Allocating the transaction price to the performance obligation in the contract \\ Introduction and applicability to construction contracts}

The objective of the allocation of the transaction price to the performance obligations is to determine the amount that the entity expects to be entitled to for each distinct good and service (performance obligation) identified (IASB 2014a). This determination is especially important for contracts with more than one performance obligation, which may be satisfied at different stages.

The principle of allocation of the transaction price to performance obligations is new as the IAS 11 implied that revenue was recognised on a contract as a whole. However, as construction contracts normally result in a single performance obligation, this step in the revenue recognition process would not have a significant impact on most construction contracts.

\section{Allocating the transaction price in terms of International Financial Reporting Standard 15}

The IASB (2014a:para. 74) created the principle that the transaction price should be allocated based on the 'standalone selling prices' of each identified performance obligation. The IASB (2014b:para. BC266) explains that the stand-alone selling price provides a faithful representation of the margins of each distinct promised good or service. The principle of using stand-alone selling prices is to determine a price that is consistent with a price that would be received if these goods or services were to be sold separately. It also exemplifies the profit margins included in the goods or services that are sold separately (IASB 2014b).

Construction contracts might have more than one performance obligation, for example, where a construction contract includes a clause to construct a toll plaza following the construction of a road, which is considered to be distinct in the context of the contract. In such cases, the IFRS 15 provides adequate guidance to allocate the transaction price to the performance obligation based on estimated standalone selling prices.

The process of allocating the transaction price makes theoretical sense and adds sufficient rigour. Stakeholders also agree with this principle (IASB 2014b:para. BC267); however, they express concerns regarding the estimation of the stand-alone selling price when the price is not directly observable. Stakeholders also express concerns over the allocation of discounts and variable consideration to different performance obligations. Both these concerns are addressed in the sections that follow.

\section{Estimating stand-alone selling prices}

As per the IFRS 15 (IASB 2014a:para. 77), the stand-alone selling price is best illustrated with the 'observable price' when a good or service is sold. Using the stand-alone selling price should normally be cost-effective and should reflect the best profit margins for decision-making purposes.

If the stand-alone selling price is not directly observable, the entity needs to estimate it by considering all facts and circumstances. In addition, when estimating the stand-alone selling price, the entity should maximise the use of observable inputs (IASB 2014a:para. 78), which is aligned with the guidance to determine fair value in the IFRS 13 (IASB 2014d). The IFRS 15 prescribes three methods through which the stand-alone selling price can be estimated: (1) the adjusted market approach, (2) the expected cost plus margin and (3) the residual approach. Each of these approaches is adequately described in the IFRS 15 to estimate the stand-alone selling price. In construction, the stand-alone selling prices are normally estimated using the expected cost plus profit margin approach as most of the transaction prices in construction contracts are estimated through cost budgeting and applying a reasonable profit margin (Hughes, Champion \& Murdoch 2015).

\section{Allocating discounts, variable consideration and subsequent treatment of changes in transaction price}

According to the IASB (2014a:para. 81), discounts exist when the stand-alone selling price exceeds the expected consideration agreed in the contract. The principle is that 
discounts are usually allocated proportionally to all performance obligations unless certain criteria are satisfied for allocation to specific performance obligations. As an exception, the IASB (2014a:para. 82) provides guidance on how to allocate a discount to specific performance obligations. The entity must sell the distinct goods or services relating to the specific performance obligation on a regular basis at a discount. In addition, the discount should clearly be identified to the specific performance obligation and the amount of the discount should 'substantially' be the same as the discounts from regular sales. The exception to allocate the discount to a specific performance would normally not be applicable to construction contracts with separate performance obligations, as construction contracts are unique and are not sold on a regular basis.

The IASB (2014a:para. 84) puts forward the principle that variable consideration can be allocated to an entire contract or to specific performance obligations if the variable consideration relates to the company's effort to satisfy the performance obligation. In the construction industry, the variable consideration is usually allocated to the entire contract as the contract represents a single performance obligation.

In order to provide consistency in revenue recognition, the IASB (2014a:para. 88) requires the subsequent changes in the transaction price, including discounts and variable consideration, to be allocated on the same basis as at contract inception.

\section{Recognising revenue when (or as) performance obligation is satisfied Introduction}

Historically, there has been diversity in the timing of revenue recognition in the construction industry (Trotman 1982). There were two options: firstly, the completed contract method, whereby revenue was recognised only upon completion of the contract and when the title of the constructed property was transferred to the customer. Secondly, the percentage of completion method, also known as the stage of completion method, was applied. The latter was the preferred method (Chartered Financial Analyst [CFA] Institute 2015; Miller \& Donnelly 1991) as it resembled the economic substance and the volume of the economic activity more closely than the completed contract method (American Institute of Certified Public Accountants [AICPA] 1981:18 879). The IASB endorses the use of the stage of completion method by including it as a recognition basis for the contract revenue and expenses in the IAS 11.

Although the requirements of the IFRS 15 could result in that the stage of completion method being applied in the IFRS 15, Henry and Holzmann (2009) argue that the conceptual basis is different in the IFRS 15:

Under existing revenue recognition principles, a manufacturer using percentage-of-completion revenue recognition would recognize revenue over the life of the contract because the act of constructing the asset is the earnings process and the method reflects the company's periodic accomplishment in that process. Under the new contract-based revenue recognition principle, the manufacturer would recognize revenue over the life of the contract because the act of constructing the asset satisfies the performance obligation and thus decreases the manufacturer's net contract liability. (p. 80)

Wagenhofer (2014) agrees that the IAS 11 was based on an income-expense matching model. Revenue for transfer of goods and services is recognised in the IFRS 15 by applying the principle of control (IASB 2014a). Transfer of control is therefore the basis of determining when performance obligations are satisfied and revenue is recognised. This changed approach from income-expense matching to the transfer of control is arguably the most significant change to the revenue recognition of construction contracts as the IAS 11 was considered to be the 'rule book' approach, with specific guidance on revenue recognition. This is now set to be replaced by the principle of control (KPMG 2014). The implication of the control approach would result in the stage of completion not being applied to all construction contracts. The IFRS 15 Agreements for the Construction of Real Estate was issued to resolve whether such contacts should be recognised over time or at a point in time. The revenue recognition guidance in IFRS 15 determines when contracts should be recognised over time or at a point in time, and should be applied to all construction contracts.

\section{The principle of control in recognising revenue in terms of International Financial Reporting Standard 15}

The IASB (2014a:para. 33) defines control as the ability to direct the use of an asset to obtain substantially all the remaining benefits from that asset. Control is transferred to the customer if the customer has the ability to direct the usage of the asset and obtain the benefits from the asset. Directing the usage of the asset includes preventing others from using the asset. Secondly, the customer must have the ability to obtain substantially all of the remaining benefits. The benefits are described as the 'right to cash inflows or savings in terms of cash outflows by using the asset' (IASB 2014a:para. 33).

Based on these principles of control, the IFRS 15 (IASB 2014a:para. 32) determines that control can be transferred either at a specific point in time, which would be the case in the sale of tradeable goods, or over a period of time, which would be the case in long-term service contracts. According to the IASB (2012), the respondents to the 2010 Discussion Paper agreed with this principle, but also raised concerns about the difficulty in applying this principle to long-term contracts. The issue was that some believed that control could only be transferred once at a particular point in time. Many users of the financial statements of construction companies were concerned that revenue from construction contracts would only be recognised once the constructed asset was completed, as this was when the customer could benefit from the usage of the asset. This, however, would not reflect the real economics of the contract (IASB 2014b:para. BC122). 
To clarify the application of control in the IFRS 15, the IASB therefore introduced three criteria to determine whether control is transferred over time. If the criteria are not met, then the performance obligation will by default be recognised at a point in time. The criteria are illustrated in Figure 2.

\section{Transfer of control over time}

Three independent criteria are identified to recognise revenue over time in terms of the IFRS 15. The last criterion is by implication a 'catch all' criterion which incorporates performance obligations not captured in criteria one and two.

\section{Customer simultaneously receives and consumes the good or service}

The IASB includes guidance to capture pure services in the form of a test, which determines whether the customer simultaneously receives and consumes the benefits as the entity performs. In cases of uncertainty, the guidance suggests that when an entity does not need to re-perform the work of another party to fulfil the remainder of a contract, then revenue should be recognised over time as a pure service (IASB 2014a:para. B4). In construction contracts, the first criterion representing a pure service would normally not be applicable as there would usually be a constructed asset as an output, which is not immediately consumed. However, according to Ernst \& Young (2015b:27), construction companies could perform certain 'distinct' services as subcontractors of another construction entity. These services include project management, supervision or engineering services and the entity would need to apply professional judgement to its contracts to determine whether the services performed were to be considered as 'pure services'.

\section{Customer controls the asset as it is created or enhanced}

In a construction contract, the entity or the customer could control the construction asset. The IASB (2014b) advocates the second criterion in situations where the customer 'clearly

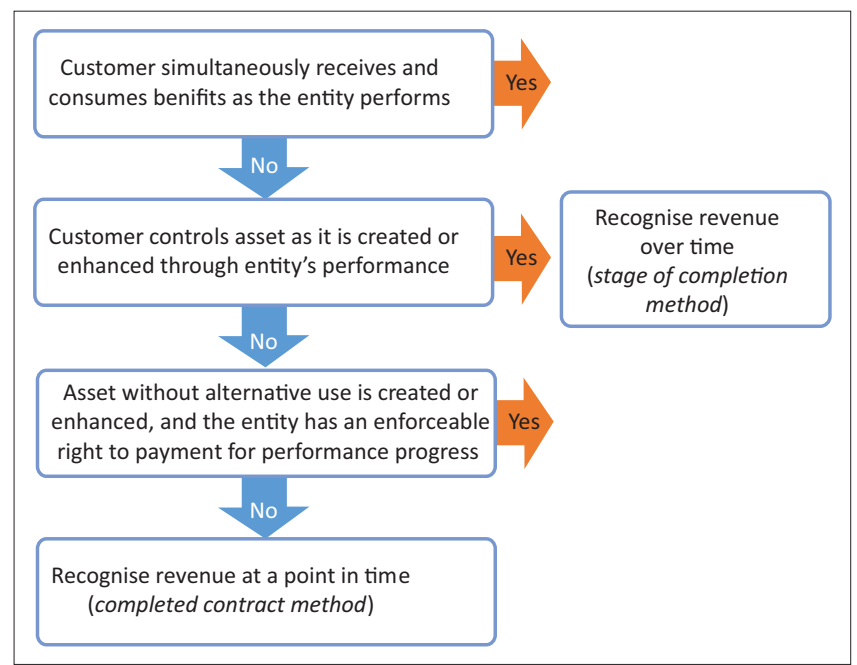

Source: International Accounting Standards Board (IASB), 2014a, 'IFRS 15 revenue from contracts with customers', in IASB (ed.), International Financial Reporting Standards: A guide through IFRS official pronouncements, issued at 01 July 2014 with extensive cross-references and other annotations, Part A1, The IFRS Foundation, London

FIGURE 2: Criteria to determine revenue recognition in International Financial Reporting Standard 15. controls' the asset as it is being created or enhanced. The IASB (2014b) uses an example of 'work-in-progress' (WIP) as an asset that could be controlled by the customer. A construction contract could be controlled by the customer if land was owned by the customer or the customer controlled the right to the WIP through the rights and obligations in the contract. The reason for this is that the customer could legally direct the use of the asset or prevent others from using it, as it was being constructed (Ernst \& Young 2015b; IASB 2014b:para. BC129).

A contractual right to the WIP is also viewed as an indicator that the customer controls the WIP throughout the duration of the contract. According to Ernst \& Young (2015b), construction contracts could include contractual terms that provide customers with a right to the WIP and, in effect, prevent others from using the asset. Not all contracts include such terms, but construction companies can alter contracts to get the desired accounting treatment to measure revenue over time as the construction contract would form the basis of revenue recognition.

Determining who controls the WIP thus becomes the main requirement to establish whether the performance obligation in the construction contract should be recognised over time or at a point in time. This requirement is based on the concept of transferring control. By implication, if the customer is controlling the constructed asset, creation or enhancement of the asset transfers the benefit to the customer as the creation or enhancement happens. Therefore, revenue should be recognised over the time of the creation or enhancement. However, if the entity is controlling the constructed asset, transfer of control only happens when the entity finally transfers the asset to the customer.

\section{Asset without alternative use is created or enhanced and the entity has an enforceable right to payment for performance progress}

In cases where control is not clearly assessed in the second criterion, the IASB has introduced a third criterion. The IFRS 15 therefore narrows the margin of judgement by introducing the final criterion that consists of two sub-requirements. The first one requires that the asset that is enhanced or created should be 'without alternative use' to the entity. The second requires that the entity should have an 'enforceable right' to receive payment for performance throughout the life of the contract.

No alternative use of the asset: The IASB (2014a:Appendix B) provides additional guidance to apply the principle of 'alternative use'. The criterion can be explained by analysing another two components, namely, 'practical limitations' and 'contractual restrictions'.

A practical limitation would be when the asset is highly customised, resulting in difficulty to sell the asset to a party other than the customer without incurring significant modification costs. The modification costs would have an adverse financial effect on the entity. The authors interpret customisation as an indicator of control because customisation prevents the entity from obtaining other benefits from the 
asset. This is because it would be unable to sell the developed asset to other parties without incurring significant costs. Nonetheless, the IASB (2014b) mentions that practical limitations should not be the determining factor in assessing whether the asset does not have an alternative use, but should be considered in conjunction with the contractual restrictions.

According to the IASB (2014a:para. B7), contractual restrictions refer to the customer having a substantive right to avoid alternative use by the entity during the construction of the asset. The contractual restrictions would provide evidence of control to the customer as they can exercise a right or have ability to restrict others from obtaining benefits from the asset being created.

Ernst \& Young (2015b:2008) correctly argues that determining alternative use would require significant judgement from the entity, especially as it needs to be determined at contract inception. It is the opinion of the authors that the IASB has provided significant guidance to determine whether the asset has an alternative use to the entity. However, contractual restrictions are subjective and each construction entity would have to assess whether the contractual restrictions in the contract were sufficient to trigger recognition over time.

The entity's right to performance payment: The principle established by the IASB holds that in the case of an asset without alternative use to the entity, the entity must have an enforceable right to payment for performance to date before revenue could be recognised over time. The substance of the enforceable right to payment needs to be considered in terms of the contract. Being only entitled to regular fixed payments per the contract might not be enough to establish the principle, as there needs to be alignment between the transferred WIP and the reasonable compensation for performance completed to date. The payment should include a reasonable profit margin for work completed to date.

The feedback summary (IASB 2012) raises questions whether the 'right to payment' needs to be in stages of the contract. The issue is how the 'right to payment' corresponds with performance in a contract and the related transfer of control to the customer. In construction, resolving the issue was justified by Van der Puil and Van Weele (2013), who stated that progress payments in construction contracts are preferred to be in line with 'milestones' in the contract. This would align the payments with the principle of satisfying the performance obligation by transferring control and also aligning with the 'output method' of measuring progress over time. However, Wagenhofer (2014) questions the progress payment requirement, remarking that such payments do not reflect a 'transfer of control'. He specifies that this is 'inconsistent' with the core principle of the standard. The focus of the IASB is not on 'progress payments', but rather on an enforceable right to payment for performance completed to date if the customer cancels the contract for reasons other than the performance of the entity. Construction entities would normally qualify to meet this criterion as they would include clauses in the contract to protect them against economic losses for construction work they performed and resources used during the contract.

\section{Measuring progress of construction contracts over time}

The IASB (2014a) has adopted a number of the principles from the IAS 11 (IASB 2013a:para. 30) to measure progress on revenue measured over time, including the input and output methods from the IAS 11. The latter is the preferred method as it conceptually reflects the performance of the entity more faithfully than the input method. The IASB's (2014b:para. $\mathrm{BC} 164)$ reason for preferring the output method is that it measures the 'value to the customer' as the entity is satisfying the performance obligation by transferring control.

Under the output method, progress is measured using surveys or milestones reached in certain construction contracts. This is consistent with what is performed in practice. The output method, however, could be difficult to apply in situations where significant time lapses occur or where work is performed in between different verifiable milestones. Construction companies should ensure that regular evidence of work performed is obtained through surveys to limit the judgements in cases where a significant amount of time lapses between different milestones.

The input method, on the other hand, reflects the efforts made by the entity to satisfy the performance obligation. From an IAS 11 perspective, this would fall in line with the cost incurred (cost-based input) method. This method is widely used as it requires less judgement and could be regarded as a mechanical calculation using information from advanced accounting software systems. The IASB (2014b) acknowledges that this method has a shortcoming insofar as a direct relationship may not exist between the transfer of control of WIP and the costs incurred on the contract. An example would be when significant costs are incurred earlier in the contract in terms of the overall budgeted costs, increasing the revenue, in line with the incurred costs. In contrast with the costs, the actual output in terms of surveys of work performed or certified work completed could indicate a lower stage of completion.

The IASB (2013a) manages the risk of unfaithful representation in the IAS 11 by excluding certain costs from those incurred to only reflect work performed. These costs are for materials delivered but not installed as well as advance payments for subcontractor work not yet performed. The IFRS 15 also makes adjustments for costs incurred which do not contribute to the performance of the entity. These costs are mostly related to inefficiencies such as abnormally wasted material and labour, which are excluded from the cost-based input method.

The IASB (2014a:para. 44) states that revenue can be recognised over time only if the entity can 'reasonably measure its progress towards complete satisfaction of the 
performance obligation'. The IAS 11 (IASB 2013a:para. 23) made specific mention that both the contract costs to complete and the stage of completion need to be reliably measured in order to recognise revenue. There are cases, however, where the outcome measurement uncertainty is so significant that revenue cannot be reliably measured over time, such as in the early stages of a construction contract. In these cases, both the IAS 11 and IFRS 15 recommend that revenue should only be recognised to the extent of the costs incurred, until the outcome can be reliably measured, if these costs are recoverable (IASB 2013b, 2014a).

\section{Conclusion}

This article evaluated the adequacy of the guidance provided by the IFRS 15 to deal with the complexities of the construction industry in order to recognise revenue derived from construction contracts. The adequacy of the revenue recognition principles proposed in the IFRS 15 was assessed through doctrinal research, a research method focusing on the core doctrines developed in practice. Reform-oriented doctrinal research was used to assess the doctrines developed in the IFRS 15 by using authoritative interpretation. Authoritative interpretation of both the old guidance in the IAS 11 and the new guidance in the IFRS 15 was supported by other practical and academic literature, which formed the basis for the reform-oriented research. In evaluating the application of the principles of the IFRS 15 to construction contracts, a structured approach was followed, based on the five-step approach applied in the IFRS 15.

Step 1 identified the nature of the contract with customers and also dealt with combining contracts and contract modifications. The validation criterion in Step 1 forms the basis for ensuring that only enforceable contracts are considered for revenue recognition purposes. The findings indicate that the IFRS 15 creates an appropriate framework to assess the rights and obligations in all contracts that form the basis for revenue recognition. The application of these validation criteria should also result in construction entities improving the stipulations of contracts and credit control over time.

The practical changes in the contract combination guidance should not result in significant changes for construction industries in practice. However, because of the continuous changing nature of construction contracts, the distinction between a contract modification and a variable price is important for construction industries. A contract modification is an agreed change to the scope and price in a contract, while a variable price is a price uncertainty in a contract that should be estimated at the inception of the contract. The IFRS 15 fulfils its objective of providing a framework for contract modifications by clarifying what a modification represents. It also identifies the three alternatives under which contract modifications could be treated: (1) a separate contract, (2) a new deemed contract or (3) an existing uncompleted contract. Construction contracts would normally be regarded as uncompleted contracts and therefore the cumulative catch-up method would be used for construction contracts because of the combined constructed output in construction contracts.
Step 2 identified the different performance obligations in a revenue contract that should be recognised separately. The guidance in the IFRS 15 is adequate to identify different performance obligation in contracts by applying the concept of distinct. This is done by providing information regarding the benefit indicator and providing factors to assess the separately identifiable indicator. Because of the integrated nature of construction contracts, one performance obligation should normally be identified. Construction entities cannot, however, assume that they will always provide one combined contractual output and need to assess the possibility of more than one performance obligation being included in the construction contract.

Step 3 determined the total transaction price included in contracts. The systematic guidance in the IFRS 15 provides a better framework for dealing with uncertainties in determining the amount of consideration in a contract, including dealing with variable prices in contracts. However, the application of the constraint on the recognition of variable consideration is problematic and could result in uncertainty in practice. Construction entities need to determine situations where uncertainties in contract pricing are so uncertain that the related revenue cannot be recognised.

Step 4 allocates the transaction price to the different performance obligations. As construction contracts normally have one combined integrated output, the transaction price does not need to be allocated to the different performance obligations. However, if different performance obligations were identified in Step 2, the transaction price should be allocated by estimating the stand-alone selling price. The guidance on the stand-alone selling prices is adequate to allocate the transaction price to the performance obligations identified.

Step 5 is very important in determining whether the revenue of construction contracts should be recognised over time or at a particular point in time, based on the concept of control. To recognise the revenue over time, the customer needs to control or be deemed to control the construction asset during the duration of the construction process. The customer normally controls the construction asset if the asset is constructed on the customer's own property. The customer can also control the WIP of the construction asset contractually, which is a question of interpreting the contract. Then the customer needs to control the WIP through the stipulations of the contract, which could be difficult to prove.

If clear control of the constructed asset by the customer is not evident as a default, the customer is also deemed to control the asset if an asset with no alternative use to the entity is created and the entity is entitled to progress payments for work done to date. In many instances, the construction asset would have an alternative use as the entity would be able to sell the constructed asset without incurring significant cost. Then the deemed control is not applicable and the entity needs to recognise the revenue at a point in time. This would 
normally be when the completed and constructed asset is transferred to the customer. However, the IFRS 15 clarifies that the alternative use could also be restricted through the stipulations of the contract. It also makes it clear that deemed control could only be applied if the entity is contractually entitled to progress payments for work done to date before revenue can be recognised over time.

The five-step revenue recognition process creates an appropriate framework for the recognition of the revenue of construction contracts. However, the application of the fivestep process is based on interpreting the rights and obligations in the construction contract, which is subjective and could lead to uncertainty in practice. Construction entities therefore need to be certain that they have clearly understood the implications of the contractual rights and obligations. All significant sources of estimating uncertainty and judgements should be disclosed to ensure that the user of the financial statements can understand the estimations and judgements made in recognising the revenue on construction contracts.

The article focused on the application of the new revenue recognition guidance in the IFRS 15 on construction contracts. Future research could evaluate the appropriateness or value relevance of the implementation of the IFRS 15 in the construction industry by reviewing issued financial statements. The views of the construction industry regarding the application of the IFRS 15 could also be assessed through surveys, interviews and even case studies. Finally, the question of whether the construction industry deals with the disclosure burden, especially regarding estimation uncertainty and judgements, could be the focus of further research.

\section{Acknowledgements}

This article was completed as part of M.v.W.'s Master's degree in International Accounting, where D.C. was the supervisor.

\section{Competing interests}

The authors have declared that no competing interest exist.

\section{Authors' contributions}

M.v.W. performed the research as part of his master's dissertation. D.C. played a major role in providing guidance from a conceptual basis. Both D.C. and M.v.W. played a role in ensuring that the dissertation was transformed into an article and addressing the critical issues in the construction industry.

\section{Ethical consideration}

This article followed all ethical standards for research without direct contact with human or animal subjects.

\section{Funding information}

This research received no specific grant from any funding agency in the public, commercial, or not-for-profit sectors.

\section{Data availability statement}

Data sharing is not applicable to this article as no new data were created or analysed in this study.

\section{Disclaimer}

The views and opinions expressed in this article are those of the authors and do not represent an official position of the University of Johannesburg.

\section{References}

American Institute of Certified Public Accountants, (AICPA), 1981, Accounting for performance of construction-type and certain production-type contracts, performance of construction-type and

Baloi, D. \& Price, A.D., 2003, 'Modelling global risk factors affecting construction cost performance', International Journal of Project Management 21(4), 261-269. https://doi.org/10.1016/S0263-7863(02)00017-0

Boland, R.J., 1989, 'Beyond the objectivist and subjectivist: Learning to read accounting as text', Accounting Organizations and Society 14(5/6), 591-604. https://doi.org/10.1016/0361-3682(89)90021-4

Chartered Financial Analyst Institute, 2015, International financial statement analysis, 3rd edn., John Wiley \& Sons Inc, Hoboken, NJ.

Chynoweth, P., 2008, 'Legal research', in A. Knight \& L. Ruddock (eds.), Advanced research methods in the built environment, pp. 28-38, Wiley-Blackwell, Oxford.

Dobler, M., 2008, 'Rethinking revenue recognition: The case of construction contracts under International Financial Reporting Standards', International Journal of Revenue Management 2(1), 1-22. https://doi.org/10.1504/IJRM.2008.018175

Ernst \& Young, 2015a, Applying IFRS in engineering and construction, IFRS Publications, UK, viewed 09 February 2016, from https://www.ey.com/Publication/vwLUAssets/ Applying_IFRS_in_Engineering_and_Construction:_The_new_revenue_ recognition_standard./\$File/Applying-Rev-Construction-Jūly2015.pdf.

Ernst \& Young, 2015b, International GAAP, Wiley \& Sons Ltd, Chichester.

Gaffikin, M., 2006, Accounting theory: Research, regulation and accounting practice, 1st edn., Pearson Education Australia, French Forest.

Gaffikin, M.J.R., 2008, Accounting theory: Research, regulation and accounting practice, Pearson Education Australia, Frenchs Forest, NSW.

Henry, E. \& Holzmann, O.J., 2009, 'Contract-based revenue', The Journal of Corporate Accounting \& Finance 20(5), 77-81. https://doi.org/10.1002/jcaf.20518

Hughes, W., Champion, R. \& Murdoch, J.R., 2015, Construction contracts : Law and management, Routledge, Abingdon, Oxon, viewed 08 August 2019, from https://Osearch.ebscohost.com.ujlink.uj.ac.za/login.aspx?direct=true\&db=nlebk $\& A N=981118 \&$ site $=$ ehost-live \&scope $=$ site

Hutchinson, T.C. \& Duncan, N., 2012, 'Defining and describing what we do: Doctrinal legal research', Deakin Law Review 17(1), 83-119. https://doi.org/10.21153/ dlr2012vol17no1art70

Inanga, E.L. \& Schneider, B.W., 2005, 'The failure of accounting research to improve accounting practice: A problem of theory and lack of communication', Critical Perspectives on Accounting 16(3), 227-248. https://doi.org/10.1016/s10452354(03)00073-X

International Accounting Standards Board (IASB), 2012, Revenue recognition: Feedback summary from comment letters and outreach, The IFRS Foundation, London.

International Accounting Standards Board, 2013a, IAS 11: Construction contracts, The IFRS Foundation, London.

International Accounting Standards Board, 2013b, IAS 18: Revenue, The IFRS Foundation, London.

International Accounting Standards Board, 2014a, 'IFRS 15 revenue from contracts with customers', in IASB (ed.), International Financial Reporting Standards: A guide through IFRS official pronouncements, issued at 01 July 2014 with extensive cross-references and other annotations, Part A1, The IFRS Foundation, London, pp. A683-A743.

International Accounting Standards Board, 2014b, 'Basis for conclusions on IFRS 15 revenue from contracts with customers', in IASB (ed.), International Financial
Reporting Standards: A guide through IFRS official pronouncements, issued at 01 July 2014 with extensive cross-references and other annotations, Part B2, The July 2014 with extensive cross-references
IFRS Foundation, London, pp. B295-B1435.

International Accounting Standards Board, 2014c, 'IAS 1 presentation of financial statements', in IASB (ed.), International Financial Reporting Standards: A guide through IFRS official pronouncements, issued at 01 July 2014 with extensive cross-references and other annotations, Part A1, The IFRS Foundation, London, pp. A752-A790

International Accounting Standards Board, 2014d, 'IFRS 13 fair value measurement', in IASB (ed.), International Financial Reporting Standards: A guide through IFRS official pronouncements, issued at 01 July 2014 with extensive cross-references and other annotations, Part A1, The IFRS Foundation, London, pp. A601-A650.

International Accounting Standards Board, 2015, IASB: Projects - work plan for IFRSs - clarification to IFRS 15 -issues emerging from TRG discussions - discussions and papers, The IFRS Foundation, London, UK, viewed 07 June 2015, from https://cdn. ifrs.org/-/media/feature/meetings/2015/march/trg-rev/rev-rec/march-2015meeting-summary.pdf 
International Accounting Standards Board, 2016, 'Basis for conclusions on IFRS 15 revenue from contracts with customers', in IASB (ed.), International Financial Reporting Standards: A guide through IFRS official pronouncements, issued at 01 July 2016 with extensive cross-references a
IFRS Foundation, London, pp. B1298-B1446.

Ivory, C., 2005, 'The cult of customer responsiveness: Is design innovation the price of a client-focused construction industry?', Construction Management and Economics 23(8), 861-870. https://doi.org/10.1080/01446190500204648

KPMG, 2014, Impacts on the construction industry of the new revenue standard, KPMG, London.

Miller, G.A. \& Donnelly, W., 1991, 'Some responses to the International Accounting Standards Committee's exposure draft on "comparability of financial statements", Journal of Corporate Accounting \& Finance 3(1), 75-81. https://doi.org/10.1002/ jcaf.3970030107

Moore Stephens, 2018, IFRS 15 and construction: What does it mean to you?, viewed 08 August 2019, from https://australia.moorestephens.com/MediaLibsAndFiles/ media/australia.moorestephens.com/Documents/Publications/Service $\% 20$ Lines/Audit\%20and\%20Assurance/IFRS-15_Construction-v1-20180502.pdf.

Morris, D., 2014, 'Entire contract theory in construction', Brief 41(3), 8-11.

Mulder, H., 2013, 'An analysis of the state of innovation in the South Africa construction industry', Master's dissertation, University of Pretoria, Hatfield, Pretoria, viewed 11 August 2017, from https://repository.up.ac.za/handle/2263/41014.

Ndlovu, H., 2017, 'Factors influencing clients' choice of standard form construction contracts: A case study of three metropolitan municipalities in Gauteng Province of South Africa', Master's dissertation, University of the Witwatersrand, Johannesburg.

Oxford University Press, 2016, Oxford Dictionaries, viewed 15 March 2016, from https://www.oxforddictionaries.com/definition/english/distinct.
Prasad, A., 2002, 'The contest over meaning: Hermeneutics as an interpretative methodology of understanding texts', Organizational Research Methods 5(1) 12-33. https://doi.org/10.1177/1094428102051003

PricewaterhouseCoopers (PwC), 2013, 'SA construction', Publications, viewed 07 June 2015, from https://www.pwc.co.za/en/assets/pdf/sa-constructiondecember-2013.pdf.

PricewaterhouseCoopers, 2014, 'INT2014-02 revenue from contracts with customers: Engineering and construction industry supplement', PwC Inform, viewed 09 February 2016, from https://inform.pwc.com/show?action=applylnform ContentTerritory\&id $=1459130306101131 \&$ tid.

Randolph, T.H. \& Ellis Jr., R.D., 2007, Interpreting construction contracts: Fundamental principles for contractors, project managers and contract administrators, American Society of Civil Engineers (ASCE), s.I., UT.

Trotman, K.T., 1982, 'Accounting for long-term construction contracts', Discussion paper, No. 3, Australian Accounting Research Foundation, Melbourne.

Van der Puil, J. \& Van Weele, A., 2013, International contracting: Contract management in complex construction projects, Imperial College Press, London.

Van der Spuy, P.V.A., 2015, 'Non-recognition of internally generated brands: Implications for the usefulness of financial statements', Journal of Economic and Financial Science 8(3), 808-822. https://doi.org/10.4102/jef.v8i3.123

Van Hoecke, M., 2011, 'Legal doctrine: Which method(s) for what kind of discipline?', in M. Van Hoecke (ed.), Methodologies of legal research: Which kind of method for what kind of discipline?, pp. 1-18, Hart Publishing, Oxford.

Wagenhofer, A., 2014, 'The role of revenue recognition in performance reporting', Accounting and Business Research 44(4), 349-379. https://doi.org/10.1080/0001 4788.2014.897867 